\title{
Celebrating 100 years: Happy Birthday, Naturwissenschaften!
}

\author{
Sven Thatje
}

Published online: 3 January 2013

(C) Springer-Verlag Berlin Heidelberg 2012

This year, Naturwissenschaften celebrates its 100th anniversary. Springer's flagship multidisciplinary science journal was founded in 1913, and the first print issue of Naturwissenschaften (NAWI) was published on January 3 of that year (Autrum 1988). Since 2009, the sub-title The Science of Nature has been published alongside the journal title; however, the original title in German remains the official name of the journal, recognizing its origins and strong connection to European history of the twentieth century.

NAWI covers all aspects of the natural sciences, focusing on articles in biology, chemistry, geology, and physics. Published monthly, the journal is dedicated to the fast publication of high-quality, peer-reviewed research. Reviews, Original Articles, Concepts and Synthesis, Short Communications, and Comments and Replies are published as onlinefirst articles before appearing in print. From 2013, the print of color is for free.

The journal was a reflection of the physical and chemical sciences of its time in its first decades; it then gradually developed to include topics of interest to the broader community in the biological sciences. Today, publications contribute mainly to questions of general biological significance and come from the chemical, biological, geological, and physical sciences.

The goal for our second century is to promote the exchange of ideas in all topics related to the biological sciences and beyond. Some changes to the structure of the journal including article types have been implemented in support of

\section{S. Thatje $(\bowtie)$}

University of Southampton, Ocean and Earth Science,

National Oceanography Centre, European Way,

Southampton SO14 3ZH, UK

e-mail: svth@noc.soton.ac.uk this strategy (Thatje 2012a). We look forward to publishing papers in fields especially relevant to the science and society of the Twenty-first century, including areas such as global change, genomics, biorobotics, and neurobiology. In order to support this development, a "Special Article Theme" section will be launched later this year.

For the 100th anniversary, the Arnold Berliner Award (Thatje 2012b) will be established in recognition of its founder who guided the development of the journal over the exceptionally long period of 22 years. The award will be given annually for the best research article published in Naturwissenschaften during the previous calendar year, and it is my special honor to announce the first awardee later this year.

Honoring the efforts of the journal's founding editor, Dr. Arnold Berliner, on the occasion of his 70th birthday, Albert Einstein wrote, "His journal cannot be thought away from the life of our time." (Einstein 1932). Eightyyears on, Naturwissenschaften remains one of the primary multidisciplinary science journals. I invite you to celebrate the journal and science, following our birthday activities throughout the year and into the journal's second century of existence.

Happy birthday, Naturwissenschaften!

\section{References}

Autrum H (1988) Arnold Berliner und die "Naturwissenschaften". Naturwissenschaften 75:1-4

Einstein A (1932) Zu Dr. Berliners siebzigstem Geburtstag. Naturwissenschaften 20:913

Thatje S (2012a) Naturwissenschaften: recent advances, changes and challenges. Naturwissenschaften 99:1-2

Thatje S (2012b) Introducing the Arnold Berliner Award. Naturwissenschaften 99:675-676 